doi: 10.52370/TISC21433NP

\title{
THE STATE OF TOURISM IN EUROPEAN UNION MEMBER STATES DURING COVID-19 PANDEMIC
}

\author{
Nemanja Pantić ${ }^{1}$; Marija Lakićevic ${ }^{2}$
}

\begin{abstract}
The Covid-19 pandemic has left an impact on the whole world and all economic activities without exception. There are already indications of the consequences, and they will be fully perceptible only after the pandemic is over, which still seems far away. One of the general characteristics of tourism is vulnerability during periods of crisis which everyone globally has to face. Since the beginning of 2020, and especially since March, a drastic drop in tourist travels on the tourism market of the European Union, or its member states, is obvious. The goal of this paper is to define a model which will be able to predict changes in tourist visits based on their movements in previous periods. The analysis includes all European Union member states and changes in the number of tourist visits on a monthly basis during 2020. The model will also enable future predictions, which is very important for tourism policy carriers, as well as for the tourism offer which can adapt to expectations.
\end{abstract}

Key Words: tourism, tourist visits, COVID 19, European Union JEL classification: Z30, Z32, C22

\section{Introduction}

The concept of a modern man implies an active role in all spheres of social life (Bird, 1992). The necessities multiply, and it becomes harder and harder to keep up with progress of the civilization (Ding et al., 2016). The reasons must be found in limitations of all resources, as well as the time that each

\footnotetext{
${ }^{1}$ Nemanja Pantić, Ph.D., Assistant Professor, University of Kragujevac, Faculty of Hotel Management and Tourism in Vrnjačka Banja, Vojvođanska 5a, 36210 Vrnjačka Banja, Republic of Serbia, +381612058758, nemanja.pantic@kg.ac.rs

${ }^{2}$ Marija Lakićević, Ph.D., Associate Professor, University of Kragujevac, Faculty of Hotel Management and Tourism in Vrnjačka Banja, Vojvođanska 5a, 36210 Vrnjačka Banja, Republic of Serbia, +38162609204, marija.lakicevic@kg.ac.rs
} 
individual can dedicate to themselves (Milne \& Ateljević, 2001). On the other hand, that everyday pace of life is exactly what requires finding that limited resource, time, that everyone has to find for themselves and their families, which is quite a contradiction in and of itself. Looking back at the historical development of civilization indicates that all motives for travelling have existed since the first human communities, and that they were not always inspired by existential needs, but also by curiosity and the need to explore outside the familiar boundaries (Cobbinah et al., 2013). The scale of these travels was recorded in XVIII century with an invention that was directly motivated by faster transport of people, goods, and money (Leković et al., 2020). The steam engine and the first industrial revolution have changed life from its foundation (Pantić, 2016). From then until today, travels motivated by tourism have not only changed the people's awareness, but also the entire system of economic functioning (Bianchi, 2003; Manzoor et al., 2019). The significance of the development of tourism is constantly increasing, which is proven by its contribution to gross domestic product and employment (Dabour, 2003). Circulation of funds in a country's economy achieves many positive direct and indirect economic effects (Ekanayake \& Long, 2012). The level of economic development is closely related to the level of tourism development (Pantić, 2017). The most developed economies have a high level of tourism contribution to the aforementioned gross domestic product and employment (Oppermann, 1993). Capital investments are a precondition to tourism development, so the awareness of local government as well as the entire country is very important (Luković \& Stojković, 2020; Meyer \& Meyer, 2015). A foreign tourist's money represents additional financial stimulus for the economy, and it has multiplicative effects (Pantić et al., 2019). Over the last three decades, the contemporary research in the fields of tourism and economics has been trying to change the perception of tourism as an exclusively economic category (Milićević et al., 2021). However, the one thing that must not be neglected is the exceptional vulnerability of tourism to potential impacts and negative economic climate (Obradović et al., 2013). In general, the catering sector suffers the most during critical periods, since it is affected the most. The evidence of that are numerous financial crises, and especially the last big global economic crisis of 2008 (Bal et al., 2016; Nasir et al., 2017). While dealing with existential and everyday problems, critical periods leave little room and time for travelling (Gokovali \& Bahar, 2006). Tourism development carriers and the entire tourism economy are impacted the most because of that. We are currently contemporaries of the COVID-19 pandemic, which is ongoing for more than a year at this point. The whole world is affected by it, and financial pressures and problems present a 
permanent danger, as well as almost guaranteed financial crisis whose negative consequences are yet to be discovered and analyzed. The emergency measures of all countries, almost without exception, have included or still include either prohibition of population movement or its limitation. Even the travels that are possible are under control and reduced to only necessary ones in such conditions, because people do not want to take risks out of fear. Summer seasons in all tourism locations have almost failed, the number of tourists has dropped severalfold, as well as the money income. Many employees in tourism businesses have lost their jobs, and further overloaded the job market. The post-crisis period, which is still not in sight, will have to result in measures which will quickly and efficiently remediate consequences of the crisis, which anyone can only speculate for now. The goal of this research is to create a model which can be used to predict a change in tourist visits on a monthly basis, based on changes in the previous period using the multiple regression analysis model.

\section{Literature overview}

Uğur and Akbiyik (2020) claim that the tourism industry was one of the most significant global markets before COVID-19. They also proved that the tertiary sector is very vulnerable to critical impacts since tourists' behavior has changed overnight from the day of proclamation of COVID19 pandemic. In less than $24 \mathrm{~h}$ most of arrangements in Europe, as well as in Asia and Africa, have been cancelled. The chance for revival of tourism economy during the post-crisis period is presented in the growth and development of travel insurance.

Madani et al. (2020) have used quantitative and qualitative methods to examine the opinions of Algiers during the COVID-19 pandemic. They have reached the result that the interest in travels has dropped by $63 \%$ in relation to the pre-pandemic period. They have also analyzed the awareness of people about the significance of tourism for economic revival after the pandemic, and reached the conclusion that up to $75 \%$ of population is aware of tourism's significance for economic growth and development. It is expected that the post-crisis period will affect the growth of demand for cheaper offers as a consequence of the evident economic crisis.

Couto et al. (2020) have emphasized the vulnerability of tourism in critical periods and the danger of negative economic consequences caused by the fall of tourist visits on a global scale. They have also indicated a very difficult post-crisis period during which a fear of travelling will be present. 
Through a survey conducted with the residents of the Azores archipelago at the beginning of COVID-19 pandemic, they reached the information that more than $70 \%$ of the population will not travel during 2020, fully aware of negative economic consequences but also of great fear of disease.

Kumudumali (2020) draws attention to the global negative effect of COVID-19 pandemic through significant economic impacts. Tourism is especially affected by the pandemic, and it is estimated that the number of international tourist arrivals will drop by 1.1 billion and that the financial loss will be around 1 trillion USD. It is also stated that the recovery will take a very long time, and that consequences will be evident in a large drop in employment, not only in the tourism economy sector, but also in businesses that are directly and indirectly related to tourism.

Khazami et al. (2020) state that COVID-19 pandemic will result in a drop in tourism traffic by more than $60 \%$, but also in a large drop in employment in the tertiary sector. The danger is present for other economic activities and businesses, and its consequences are yet to be perceived and measured. For that reason, it is very important that economic policy carriers define, approve and implement post-crisis measures which will revitalize not only tourism but also the entire economy in a timely manner.

Lee and Chen (2020) have defined a regressive model which predicts an income of tourists' funds during the post-crisis period. They emphasized the inconceivable consequences of COVID-19 pandemic and a very long revitalization period for all economic activities, especially tourism. According to them, psychological consequences of fear of travel will remain much longer than the crisis itself. Tourism is an activity which may have a significant influence on the economic, social, functional and physiognomic structure of areas (Sagić et.al, 2019). It is something that is yet to be the topic of research and detailed analysis. An entirely new policy will be needed for attracting primarily foreign tourists. We should give a chance to new forms of tourism as the future development initiators of the entire tourism economy.

Aburumman (2020) has affirmed the great danger from a long-standing critical period which will ensue in the tourism industry. The crisis caused by the COVID-19 pandemic will remain in tourism much longer than in other economic activities. That has once again shown considerable vulnerability of tourism to impacts of this type. According to him, the solution for tourism must be sought in MICE industry. Furthermore, small 
companies represent the essence of the economic recovery during the postcrisis period. In UAE, tourism contributed to $11.3 \%$ of GDP. It is expected that this percentage will drop severalfold because, among other things, the number of flights in 2020 is $86.7 \%$ less than 2019 .

\section{Theoretical overview of the state of tourism in member states of the European Union in 2020}

The introductory assumptions and stances about the crisis caused by COVID-19 pandemic for tourism are the subject of further analysis. The global phenomenon of tourism that has been affected by the global pandemic can be viewed through the change in the number of tourists on a monthly basis. Table 1 contains the data on the procedural change of tourist visits on a global scale in comparison to the same period in the previous year. In order to compare the changes, an internationally accepted segmentation by regions has been made.

Table 1: Percentage monthly change of tourist visits in 2020 by regions compared to the same period last year

\begin{tabular}{|c|c|c|c|c|c|c|c|c|c|c|c|c|}
\hline \multirow{2}{*}{ Region } & \multicolumn{10}{|c|}{ Month } \\
\cline { 2 - 13 } & Jan & Feb & Mar & Apr & May & Jun & Jul & Aug & Sep & Oct & Nov & Dec \\
\hline Africas & 0 & -1 & -36 & -50 & -90 & -91 & -89 & -85 & -84 & -83 & -82 & -80 \\
\hline America & 0 & 3 & -50 & -94 & -93 & -92 & -88 & -87 & -83 & -80 & -78 & -71 \\
\hline Asia & -9 & -54 & -82 & -98 & -99 & -98 & -95 & -95 & -96 & -96 & -95 & -95 \\
\hline Europe & 5 & 2 & -61 & -98 & -96 & -88 & -71 & -67 & -72 & -77 & -87 & -85 \\
\hline $\begin{array}{c}\text { Meadle } \\
\text { East }\end{array}$ & 6 & -1 & -68 & -99 & -99 & -99 & -94 & -93 & -91 & -88 & -87 & -90 \\
\hline World & -1 & -16 & -64 & -97 & -96 & -91 & -80 & -77 & -79 & -83 & -88 & -85 \\
\hline
\end{tabular}

Source: Prepared by authors based on data from UNWTO

At the start of the year, when the scale of the pandemic could not have been foreseen, there were almost no changes in Africa and America when compared to the same period last year. Europe and Middle East even experienced a slight increase in tourist visits of 5\% and 6\% respectively. Since the first patients and victims of COVID-19 appeared in China at the end of 2019, there was a drop in tourist visits of 9\% in January, 2020. There were no significant global changes in the number of visits in January, since a drop of only $1 \%$ is negligible. A sudden drop of visits in Asia of up to $54 \%$ continued throughout February, while the rest of the world went through insignificant changes. There was even a recorded increase of 3\% in America. As COVID-19 pandemic significantly impacted the whole 
world in March, there were dramatic changes and drops in tourist visits on a global scale. Even in March there was a drop of $36 \%$ in Africa and up to $82 \%$ in Asia. From April to the end of 2020, a dramatic drop continued throughout the world, being over $90 \%$ in majority of cases, which is proof of almost total shutdown of tourism. From April to December there were almost no changes or positive movements, since the measures in force prohibited more significant and massive population movement. Furthermore, people's caution and fear of disease have been a major contribution to these changes.

Table 2: Percentage monthly change of tourist visits in 2020 in EU countries compared to the same period last year

\begin{tabular}{|c|c|c|c|c|c|c|c|c|c|c|c|c|}
\hline & \multicolumn{12}{|c|}{ Month } \\
\hline & 1 & 2 & 3 & 4 & 5 & 6 & 7 & 8 & 9 & 10 & 11 & 12 \\
\hline Aut & 11 & 13 & -69 & -99 & -98 & -76 & -41 & -35 & -43 & -76 & -95 & -93 \\
\hline Bel & 7 & 6 & -69 & -99 & -99 & -85 & -56 & -68 & -75 & -86 & -88 & -92 \\
\hline Bul & 9 & 5 & -44 & -89 & -87 & -75 & -66 & -68 & -56 & -45 & -54 & -65 \\
\hline Cro & 2 & 1 & -81 & -100 & -98 & -76 & -51 & -53 & -82 & -90 & -87 & -85 \\
\hline Сур & 4 & 0 & -67 & -100 & -100 & -98 & -88 & -81 & -83 & -77 & -95 & -91 \\
\hline Cze & 8 & 1 & -74 & -100 & $\begin{array}{l}99 \\
\end{array}$ & -89 & -69 & -63 & -75 & -68 & -64 & -76 \\
\hline Den & 2 & 7 & -66 & -97 & -96 & -87 & -69 & -61 & -66 & -76 & -86 & -87 \\
\hline Est & 13 & 9 & -64 & -99 & -97 & -84 & -58 & -61 & -80 & -89 & -90 & -90 \\
\hline Fin & 9 & 2 & -58 & -98 & -98 & -94 & -84 & -83 & -88 & -89 & -89 & -89 \\
\hline Fra & 3 & 5 & -68 & -89 & -91 & -85 & -64 & -61 & -59 & -68 & -92 & -93 \\
\hline Ger & 2 & 1 & -71 & -97 & -95 & -83 & -62 & -60 & -63 & -77 & -92 & -95 \\
\hline Gre & 20 & 25 & -47 & -96 & -98 & -94 & -85 & -73 & -74 & -66 & -98 & -95 \\
\hline Hun & -15 & -15 & -15 & -100 & -100 & -100 & -56 & -56 & -56 & -62 & -64 & -78 \\
\hline Irl & 0 & 4 & -56 & -65 & $\begin{array}{l}-68 \\
\end{array}$ & $\begin{array}{l}-78 \\
\end{array}$ & -81 & -86 & -79 & -89 & -84 & -92 \\
\hline Ita & 4 & 8 & -83 & -90 & -84 & -72 & -55 & -45 & -47 & -66 & -75 & -82 \\
\hline Lat & 11 & 14 & -61 & -98 & -97 & -76 & -39 & -41 & -79 & -88 & -89 & -90 \\
\hline Lit & 5 & 5 & -63 & -95 & -95 & -85 & -66 & -72 & -84 & -85 & -83 & -89 \\
\hline Lux & 0 & 0 & -56 & -96 & -93 & -68 & -49 & -37 & -43 & -44 & -46 & -58 \\
\hline Mal & 17 & 16 & -57 & -100 & -100 & -100 & -84 & -66 & -82 & -83 & -92 & -94 \\
\hline $\mathrm{Ned}$ & 5 & 4 & -66 & -98 & $\begin{array}{l}-92 \\
\end{array}$ & $\begin{array}{l}-71 \\
\end{array}$ & -42 & -46 & -57 & -84 & -90 & -92 \\
\hline Pol & 4 & 8 & -54 & -56 & -63 & -61 & -68 & -72 & -65 & -78 & -74 & -71 \\
\hline Por & 11 & 7 & -63 & -99 & -99 & -96 & -84 & -71 & -74 & -78 & -88 & -85 \\
\hline Rom & -9 & -10 & -80 & -99 & -100 & -95 & -90 & -90 & -89 & -90 & -89 & -92 \\
\hline Svk & 20 & 6 & -67 & -100 & $\begin{array}{l}-99 \\
\end{array}$ & -86 & -51 & -48 & -66 & -91 & -94 & -95 \\
\hline Slo & 7 & 2 & -80 & -100 & -99 & -83 & -67 & -67 & -74 & -88 & -99 & -98 \\
\hline Esp & 1 & 1 & -64 & -100 & -100 & -98 & -75 & -76 & -87 & -87 & -90 & -92 \\
\hline Swe & 1 & 5 & -64 & -91 & -88 & -88 & -86 & -82 & -69 & -63 & -65 & -75 \\
\hline
\end{tabular}

Source: Prepared by authors based on data from UNWTO 
The European Union member states are the subject of this research. Table 2 contains monthly changes of the number of tourists for all of them.

At the global scale, there was a decline, especially in February (particularly in Asia). A significant increase in tourism is evident in this period. Greece has experienced exceptional growth in tourist traffic by $20-25 \%$ compared to the same period last year. A similar increase was recorded in Slovakia and Malta. Other member states of the European Union also recorded an increase, but not as significant as in the aforementioned ones. However, the changes showed a significant growth trend recorded in several percentage points. In March there was an almost disproportionate change and a total turning point on the European Union's tourism market. The sudden drop was recorded in all member states, without exception. It may be worth noting Hungary's example, which retained the drop trend from January and February, and there was an identical 15\% drop in March which, at the moment, was by far the lowest drop in the entire European Union. The largest drop by $83 \%$ happened in Italy, and the group of states whose drop in March was over $80 \%$ includes Croatia, Slovenia and Romania. The following two months (April and May) experienced the reduction of tourist visits to the historically minimal limit. In almost all countries the drop was significantly over $90 \%$ (in the majority of such situation a drop by $98 \%$ and 99\% was recorded). Hungary's example should be noted once again, which showed a constant drop trend, identical for the first 3 months (15\%). In April and May there was an absolute drop of $100 \%$, i.e., a period without any tourist visits. Hungary is not the only one faced with this situation. This group of states also includes Cyprus, Croatia, Czech Republic, Malta, Romania, Slovakia, Slovenia, and Spain. However, special note must be made for the dependence of the aforementioned states on tourism economy businesses. Namely, the economic effects and consequences will be perceivable only after the crisis is over, and they will not affect the states dependent on tourism in the same manner as the ones that are not. It is to be expected that this drop of tourism activity will especially affect Malta, Cyprus, Spain, and Greece. The other states, regardless of how affected they are by the drop of tourism activities, will not suffer such economic impact.

During summer months (June, July and August) as a period of the most numerous tourist visits, the situation was still significantly unfavorable, but the drop trend was partially reduced following the previous months. On average, that drop was $10-15 \%$ less than previous months, which is still a historically low result. Austria and Luxembourg had the lowest drop 
percentage during the aforementioned period, which did not exceed $50 \%$ in all three months. Cyprus still had record-breaking percentage drops, above $81 \%$, which is a significant economic impact for a tourism-dependent state. Malta and Romania were in a similar situation.

By the end of the year there were no significant changes and positive trends. The COVID-19 pandemic does not show any signs of weakening. Almost one year after the pandemic started, very negative trends are still perceived, without indications for positive tendencies. The end of the year, in December, did not show any progress in tourist visits in relation to the previous months.

\section{Interdependence of tourist travels in member states of the European Union}

The global phenomenon of tourism implies a large possibility and a wide choice of tourist destinations in offer (Zdravković \& Peković, 2020). The development of all forms of traffic enables relatively easy and fast transport all over the world (Khan et al., 2020). The globetrotter concept became a standard term for an increasing number of tourists during the past decade, who can boast the number of countries and continents they have visited (Hrubcovaa, 2015; Stukalo et al., 2018). Reasons for intercontinental travels range from purely tourism-related to business-related, which have been more and more present during the past ten years (Slavković \& Slavković, 2019). Nonetheless, regardless of the situation, it is obvious that tourist visits from neighboring countries and mostly from the same continent is still dominant (Ivanov \& Webster, 2013). The following table shows member states of the European Union and top five countries whose tourists visit them the most. The stated claims that the most frequent tourists are residents of neighboring countries and of the same continent are to be confirmed by analysis.

Table 3 contains percentages indicating tourists' participation in total tourist visits next to the state name. In Austria, the most frequent visitors are citizens of Germany, up to 46 percent. In Belgium, the structure of foreign visitors is diversified, with guests from the Netherlands being the majority with $23 \%$, followed by tourists from France, Germany and Portugal. Tourists from Germany visit Croatia the most for numerous reasons, regardless of not being neighboring countries. The standard of living in Germany makes vacation in destinations that are still too expensive for us possible. After Germans, guests from Slovenia, Austria, 
Italy and Poland have similar percentage. It is again confirmed that the standard of living is one of the main factors for choosing tourist visits. This is especially noticeable in the case of Germany, which is ranked in top five positions in almost all member states of the European Union. As stated, tourists in Austria and Croatia are also dominant, but also in the Czech Republic, Denmark, France, Greece, Italy, Lithuania, the Netherlands, Poland and Romania, with over $20 \%$ participation for all aforementioned states. It is evident that all of these states are exceptionally tourismdependent on the visitors from Germany. Every financial or any other crisis in Germany will leave especially significant consequences on tourism development in states where German citizens are dominant tourists.

Table 3: Interdependence of tourist travels in EU contries

\begin{tabular}{|c|c|c|c|c|c|c|}
\hline & \multicolumn{5}{|c|}{ Inbound arrivals } & Other \\
\hline Aut & Ger $(46 \%)$ & Ned $(7 \%)$ & Swi (5\%) & Ita $(4 \%)$ & Ire (3\%) & $(35 \%)$ \\
\hline Bel & Ned $(23 \%)$ & Fra $(16 \%)$ & Ger (12\%) & Por $(11 \%)$ & $\operatorname{Esp}(4 \%)$ & $(29 \%)$ \\
\hline Bul & $\operatorname{Rom}(12 \%)$ & $\operatorname{Ger}(12 \%)$ & Tur $(8 \%)$ & Gre (8\%) & Rus $(6 \%)$ & $(54 \%)$ \\
\hline Cro & $\operatorname{Ger}(17 \%)$ & Slo $(9 \%)$ & Aut (9\%) & Ita (7\%) & Pol (6\%) & $(52 \%)$ \\
\hline Cyp & UK $(35 \%)$ & Rus (22\%) & Isr $(6 \%)$ & Gre (5\%) & Ger $(5 \%)$ & $(27 \%)$ \\
\hline Cze & Ger $(20 \%)$ & Svk (7\%) & Pol (6\%) & USA $(5 \%)$ & Rus (5\%) & $(57 \%)$ \\
\hline Den & $\operatorname{Ger}(27 \%)$ & Nor $(15 \%)$ & Swe (13\%) & UK $(8 \%)$ & USA $(6 \%)$ & $(31 \%)$ \\
\hline Est & Fin $(43 \%)$ & Rus (11\%) & Lat $(7 \%)$ & $\operatorname{Ger}(6 \%)$ & Swe (3\%) & $(30 \%)$ \\
\hline Fin & Rus (12\%) & Swe (11\%) & Ger $(9 \%)$ & UK (7\%) & Chi (6\%) & $(55 \%)$ \\
\hline Fra & Ger (14\%) & UK (14\%) & Bel (12\%) & Ita $(8 \%)$ & Swi $(8 \%)$ & $(44 \%)$ \\
\hline Ger & Ned $(12 \%)$ & Swi $(9 \%)$ & UK $(7 \%)$ & USA $(7 \%)$ & Aut (5\%) & $(60 \%)$ \\
\hline Gre & Ger (14\%) & UK (11\%) & Bul (10\%) & Ita $(5 \%)$ & N.M. $(5 \%)$ & $(55 \%)$ \\
\hline Hun & $\operatorname{Rom}(16 \%)$ & Ger (13\%) & Svk (11\%) & Aut (8\%) & Cze (6\%) & $(46 \%)$ \\
\hline Irl & UK (46\%) & USA (14\%) & Ger $(6 \%)$ & Fra $(5 \%)$ & Spa $(4 \%)$ & $(25 \%)$ \\
\hline Ita & $\operatorname{Ger}(20 \%)$ & USA (8\%) & Fra $(8 \%)$ & UK $(6 \%)$ & Chi (5\%) & $(53 \%)$ \\
\hline Lat & Rus (13\%) & $\operatorname{Ger}(12 \%)$ & Lit (10\%) & Est (9\%) & Fin $(6 \%)$ & $(50 \%)$ \\
\hline Lit & Ger $(12 \%)$ & Blr $(11 \%)$ & Rus (10\%) & Pol (10\%) & Lat $(9 \%)$ & $(48 \%)$ \\
\hline Lux & Bel $(20 \%)$ & $\operatorname{Ned}(17 \%)$ & $\operatorname{Ger}(14 \%)$ & Fra $(13 \%)$ & UK (7\%) & $(29 \%)$ \\
\hline Mal & UK (26\%) & Ita (16\%) & Ger (8\%) & Fra $(8 \%)$ & Pol (4\%) & $(38 \%)$ \\
\hline $\mathrm{Ned}$ & Ger $(30 \%)$ & Bel (13\%) & UK (12\%) & USA $(8 \%)$ & Fra $(5 \%)$ & $(32 \%)$ \\
\hline Pol & $\operatorname{Ger}(25 \%)$ & UK (8\%) & $\operatorname{Ukr}(6 \%)$ & USA (5\%) & Ita $(4 \%)$ & $(52 \%)$ \\
\hline Por & UK (14\%) & $\operatorname{Esp}(14 \%)$ & Fra (12\%) & $\operatorname{Ger}(11 \%)$ & $\operatorname{Bra}(6 \%)$ & $(43 \%)$ \\
\hline Rom & Ger (12\%) & Isr (10\%) & Ita $(9 \%)$ & Fra $(6 \%)$ & USA $(6 \%)$ & $(57 \%)$ \\
\hline Svk & Cze (31\%) & Ger $(9 \%)$ & Pol (9\%) & Hun $(5 \%)$ & Aut (4\%) & $(42 \%)$ \\
\hline Slo & Ita (15\%) & $\operatorname{Ger}(11 \%)$ & Aut (9\%) & Cro (5\%) & Ned $(4 \%)$ & $(56 \%)$ \\
\hline Esp & UK $(23 \%)$ & Ger $(14 \%)$ & Fra $(14 \%)$ & Ita $(5 \%)$ & $\operatorname{Ned}(5 \%)$ & $(39 \%)$ \\
\hline Swe & Den $(16 \%)$ & Nor $(15 \%)$ & Fin $(12 \%)$ & $\operatorname{Ger}(11 \%)$ & UK $(6 \%)$ & $(40 \%)$ \\
\hline
\end{tabular}

Source: Prepared by authors based on data from WTTC 
The example of Germany and its structure of foreign visitors shows deviations from other member states of the European Union. Namely, the most frequent visitors in Germany are the Dutch, with 12\% participation; in other words, there are no dominant foreign tourists. The participation of top five groups of tourists is approximately $10 \%$. Germany is a very multicultural environment with the usual significant participation of workforce, so tourists visit it for a number of reasons. The final column in Table 3 shows participation of the rest of the world in the total tourist visit number, and it is noticable that in Germany's case the percentage is highest $-60 \%$. Such structure is not present in any other member state of the European Union. In most member states, global participation is significantly under $50 \%$. For example, Ireland is visited by only $25 \%$ of tourists from the rest of the world. Its top five visitors together comprise $75 \%$ of all tourists. Reasons for that lie in Ireland's geographical position, whose island character significantly affects the guest structure. Furthermore, the standard of living and prices of tourist services resulting from it leave room only for those with "the deepest pockets". Participation of tourists from USA is significant, up to $14 \%$. The USA tourists are significant tourist potential in the Czech Republic, Denmark, Germany, Italy, the Netherlands, Poland and Romania. Therefore, the Old Continent is an exceptionally attractive tourist destination for visitors from the USA, which once again confirms the global character of tourism.

Viewing the European Union as a whole, the most significant tourist visitors are mostly residents of the member states themselves. This shows that the member states of the European Union are connected with each other to a large extent, geographically, economically, and tourism-wise. During critical periods, this connection is a "double-edged sword". Negative fluctuations on the global market are easily and quickly transferred to everyone for that exact reason. On the other hand, striving for harmonization and compatibility of economic and other policies has its strong points. The effects of all measures and instruments will quickly become evident since they can be followed on a larger sample.

All data and conclusions stated clearly indicate the significant vulnerability of tourism, especially in situations which the entire world faces because of COVID-19 pandemic. The post-crisis period, which is still not in sight, will be a difficult and long process. The possibility of precise predictions of future movements is of great importance, for approval of measures as well as for expectations. 


\section{Research methodology}

Based on the data collected, a multiple regressive analysis was conducted to answer the question of how a group of independent variables can predict a dependent variable. In this case, the independent variable is represented by the change in the number of tourists on a monthly basis in member states of the European Union, while the dependent variable is defined as the change of tourist visits in January 2021.

The general model of a multiple linear model can be presented as follows (Alexopoulos, 2010):

$$
Y=\beta_{0}+\beta_{1} X_{1}+\beta_{2} X_{2}+\ldots \ldots . .+\beta_{m-1} X_{m-1}+\varepsilon
$$

in which

$\mathrm{Y}$ - dependent variable (change in the number of tourists for January 2021) $X_{1}, X_{2}, \ldots \ldots, X_{m-1}-$ independent variable (change in the number of tourists from January to December 2020)

Regressive function can be presented as follows (Alexopoulos, 2010):

$$
\widehat{Y_{l}}=b_{0}+b_{1} X_{1 i}+b_{2} X_{2 i}+\ldots \ldots .+b_{m-1} X_{m-1}
$$

We have formulated two hypotheses related to the change in the number of tourists:

$\boldsymbol{H}_{0}-$ regressive model is well defined and the change in the number of tourists in January 2021 can be predicted with certainty;

$\boldsymbol{H}_{\boldsymbol{I}}-$ regressive model is not well defined and the change in the number of tourists in January 2021 cannot be predicted with certainty.

\section{Results and discussion}

Regressive analysis is used to obtain the model which will enable prediction of changes in tourist visits on a monthly basis. Percentage changes on a monthly level in member states of the European Union are 
independent variables of the model. January 2021 is the dependent variable, whose movement should be calculated based on the set model.

Table 4: Validity of the model

\begin{tabular}{|c|c|c|c|c|}
\hline Model & $\mathbf{R}$ & $\mathbf{R}^{\mathbf{2}}$ & Adjusted R Square & Sig \\
\hline 1 & .989 & .978 & .967 & .002 \\
\hline
\end{tabular}

Source: Author's calculations in SPSS

The model should be evaluated first, indicated by the data in Table 4. The coefficient R2 is the determining coefficient which indicates which part of the dependent variable's variance is explained by the model. Since the samples are mostly limited, i.e., small, Adjusted R2 is commonly taken into consideration, which in this case is 0.967 . This means that the created model explains almost $97 \%$ of the independent variable's variance (percentage of changes for January 2021). This means that the established model is very good and enables further interpretation of results. Furthermore, statistical significance of the results obtained, which in this case is $p=0.002$, is very important as well, which means that the obtained results have statistical significance as well.

Table 5: Results of multiple regression analysis

\begin{tabular}{|c|c|c|c|c|c|c|}
\hline & Beta & Std.Err. of Beta & B & Std.Err. of B & t & Sig. \\
\hline Const' $^{\text {b }}$ & & & 4.684 & 0.654 & 1.652 & 0.001 \\
\hline Jan'20 & 0.029 & 0.132 & 0.135 & 0.135 & 0.109 & 0.000 \\
\hline Feb '20 & -0.165 & 0.110 & -0.249 & 0.114 & -2.264 & 0.001 \\
\hline Mar'20 & 0.232 & 0.154 & 0.358 & 0.215 & 1.549 & 0.002 \\
\hline Apr'20 & 0.062 & 0.126 & 0.267 & 0.186 & 0.697 & 0.001 \\
\hline May '20 & -0.093 & 0.178 & -0.549 & 0.143 & -1.265 & 0.000 \\
\hline Jun'20 & 0.459 & 0.164 & 0.326 & 0.110 & 1.965 & 0.001 \\
\hline Jul'20 & -0.137 & 0.287 & -0.167 & 0.194 & -1.641 & 0.004 \\
\hline Aug '20 & 0.384 & 0.492 & 0.367 & 0.356 & 0.369 & 0.005 \\
\hline Sep'20 & 0.716 & 0.159 & 0.597 & 0.226 & 1.293 & 0.003 \\
\hline Oct'20 & -0.281 & 0.249 & 0.431 & 0.267 & 1.647 & 0.006 \\
\hline Nov'20 & 0.549 & 0.364 & 0.228 & 0.341 & -0.326 & 0.002 \\
\hline Dec '20 & 0.691 & 0.227 & 0.364 & 0.397 & 0.746 & 0.001 \\
\hline
\end{tabular}

Source: Author's calculations in SPSS

After considering the model's justification, it is important to determine how much each variable in the model contributes to the prediction of the dependent variable of our model. Beta coefficients in Table 5 and their absolute values give that information. They are clearly highest for 
September (0.716), December (0.691) and June (0.459), while the lowest ones are for January (0.029), April (0.062) and May (0.093). Furthermore, as with the previously considered justification of the model, statistical significance of the results obtained is important. The level for all months is $\mathrm{p}<0.005$. This proves the zero hypothesis.

$\boldsymbol{H}_{\boldsymbol{0}}-$ regressive model is well defined and the change in the number of tourists in January 2021 can be predicted with certainty, which enables formulation of regressive equation.

$$
\begin{gathered}
\text { Jan_21 }=0.135 * \text { Jan_20 }-0.249 * \text { Feb_20 }+0.358 * \text { Mar_20 }+ \\
0.267 * \text { Apr_20 }-0.549 * \text { May_20 }+0.326 * J u n \_20-0.167 * J u l \_20+ \\
0.367 * \text { Aug_20 }+0.597 * \text { Sep_20 }+0.431 * \text { Oct_20 }+0.228 * N o v \_20+ \\
0.364 * \text { Dec_20 }
\end{gathered}
$$

\section{Conclusion}

The development of human civilization has enabled a life which is not focused solely on fulfilling existential needs. The need to travel dates back to the first human communities. What changed to this day, aside from the scope of those travels, are the motives that inspire them. A contemporary human will travel a lot in order to learn about cultural and historical heritage and cultures of other nations. He will dedicate a lot of time as well as significant finances for that. Regardless of the fact that tourism has become a real need, its vulnerability remains one of its main characteristics. It is related to critical periods which may cause an even bigger crisis on the tourism market. The current COVID-19 pandemic has left and will leave great consequences on the lives and standards of living of people all over the globe. Tourism sector will also pay a steep price. The aforementioned vulnerability of tourism surfaced globally very quickly. At the start of the year, especially from March 2020, is measured a drastic drop in tourist visits on a global scale. The reasons for that arise from the need for prediction as one of the main assumptions of modern economy. If it were possible to create a model which would be able to predict tourists' monthly movements based on the changes in the previous period, we would be able to predict future changes with ease. This will be of great use to tourism policy and offer carriers, because successful business depends on precise predictions. All assumptions made by the established model are fulfilled and they have enabled a formulation of a regressive equation. However, what should be paid attention to is the model's limitation. It is created based on the movement of changes in tourist visits in 2020, which represents the 
model's temporal limitation. Furthermore, the situation taken into consideration is inadequate for the situation in peaceful condition, meaning that it should be checked whether the aforementioned model presents realistic situations outside of a critical situation. The possibility of expanding the temporal range and checking the model's adequacy in peaceful conditions is a task for future researchers. What is certain is that the COVID-19 pandemic will last for a significant amount of time. The consequences can only be glimpsed at for now, and we will be able to fully measure and understand them after the pandemic is over. Furthermore, their remediation will be a long-lasting process, and overcoming the consequences of the crisis and returning the world to a pre-pandemic situation depends on the economic policy carriers and their knowledge and experience.

\section{References}

1. Aburumman, A. A. (2020). COVID-19 impact and survival strategy in business tourism market: the example of the UAE MICE industry. Humanities and Social Sciences Communications, Vol. 7, No. 1, 141-150.

2. Alexopoulos E. C. (2010). Introduction to Multivariate Regression Analysis. Hippokratia, Vol. 14, No. 1, 23-28.

3. Bal, H., Akça, E. E., Bayraktar, M. (2016). The Contribution of Tourism to Economic Growth: A Research on the Turkey. Journal of academic approaches, Vol. 7, No. 1, 1-20.

4. Bianchi, R. V. (2003). Place and power in tourism development: tracing the complex articulations of community and locality. Revista de Turismo y Patrimonio Cultural, Vol. 1, No. 1, 13-32.

5. Bird, R. M. (1992). Taxing Tourism in Developing Countries. World Development, Vol. 20, No. 8, 1145-1158.

6. Cobbinah, P. B., Black, R., Thwaites, R. (2013). Tourism Planning in Developing Countries: Review of Concepts and Sustainability Issues. International Journal of Social, Human Science and Engineering, Vol. 7, No. 4, 313-320.

7. Couto, C., Castanho, R. A., Pimentel, P., Carvalho, C., Sousa, A., Santos, C. (2020). The Impacts of COVID-19 Crisis over the Tourism Expectations 
of the Azores Archipelago Residents. Sustainability, Vol. 12, No. 5, 76127626.

8. Dabour, N. (2003). Problems and prospects of sustainable tourism development in the OIC countries: Ecotourism. Journal of Economic Cooperation, Vol. 24, No. 1, 25-62.

9. Ding, D, Lew, A., Pin T. N. (2016). Tourism and Economic Growth. Journal of Travel Research, Vol. 55, No. 4, 454-464.

10. Ekanayake, E. M., Long, A. E. (2012). Tourism Development and Economic Growth in Developing Countries. The International Journal of Business and Finance Research, Vol. 6, No. 1, 51-63.

11. Gokovali, U., Bahar, O. (2006). Contribution of Tourism to Economic Growth: A Panel Data Approach. Anatolia, Vol. 17, No. 2, 155-167.

12. Hrubcovaa, G., Loster, T., Obergrubera, P. (2015). The Economic Effects of Tourism in the Group of the Least Developed Countries. Third global conference on business, economics, management and tourism, Rome, 39(2), 476-481.

13. Ivanov, S.H., Webster, C. (2013). Tourism's Contribution to Economic Growth: A Global Analysis for the First Decade of the Millennium. Tourism Economics, Vol. 19, No. 3, 477-508.

14. Khan, A., Bibi S., Lorenzo, A., Lyu, J., Babar, Z.U. (2020). Tourism and Development in Developing Economies: A Policy Implication Perspective. Sustainability, Vol. 12, No. 4, 6312-6326.

15. Khazami, N., Lakner, Z., Nefzi, A. (2020). Pandemic and tourism: Repreparation of tourism post COVID- 19. Journal of Hotel and Business Management, Vol. 9, No. 2, 1-5.

16. Kumudumali, S. H. T. (2020). Impact of COVID-19 on Tourism Industry: A Review, https://mpra.ub.uni-muenchen.de/102834/1/MPRA paper102834.pdf, (12 January 2021).

17. Lee, C. C., Chen, M. P. (2020). The impact of COVID-19 on the travel and leisure industry returns: Some international evidence. Tourism Economics, Vol. 20, No. 10, 1-22. 
18. Leković, M., Cvijanović, D., Pantić, N., Stanišić, T. (2020). Evaluative bibliometric analysis of recent trends in rural tourism literature. Economics of Agriculture, Vol. 67, No. 4, 707-720.

19. Luković, S., Stojković, D. (2020). Covid-19 pandemic and global tourism. Hotel and Tourism Management, Vol. 8, No. 2, 79-88.

20. Madani, A., Boutebal, S. E., Benhamida, H., Bryant, C. R. (2020). The Impact of Covid-19 Outbreak on the Tourism Needs of the Algerian Population. Sustainability, Vol. 12, No. 7, 8856-8867.

21. Manzoor, F., Wei, L., Asif, M., Zia ulHaq, M., Rehman, H. (2019). The Contribution of Sustainable Tourism to Economic Growth and Employment in Pakistan. International Journal of Environmental Research and Public Health, Vol. 16, No. 19, 3785-3793.

22. Meyer, D. F., Meyer, N. (2015). The role and impact of tourism on local economic development: A comparative study. African Journal for Physical, Health Education, Recreation and Dance (AJPHERD), Vol. 21, No. 1, 197-214.

23. Milićević, S., Bošković, N., Lakićević, M. (2021). Sustainable tourism development in mountain areas in Šumadija and Western Serbia. Journal of Mountain Science, Vol. 18, No. 3, 735-748.

24. Milne, S., Ateljević, I. (2001). Tourism, economic development and the global-local nexus: Theory embracing complexity. Tourism Geographies, Vol. 3, No. 4, 369-393.

25. Nasir, S., Luljeta, S., Murat, S. (2017). The impact of tourism on economic growth in the Western Balkan countries: An empirical analysis. International Journal of Business and Economic Sciences Applied Research (IJBESAR), Vol. 10, No. 2, 19-25.

26. Obradović, S., Leković, M., Pantić, N. (2013). Consequences of Global Financial Crisis for Tourism Industry in Montenegro and Serbia: a Comparitive Analysis. Actual Problems of Economics, Vol. 6, No. 1, 373380.

27. Oppermann, M. (1993). Tourism space in developing countries. Annals of Tourism Research, Vol. 20, No. 3, 535-556. 
28. Pantić, N. (2016). Impact of tourism on macroeconomic stability and economic development of the Republic of Serbia. The First International Scientific Conference "Tourism in function of development of the Republic of Serbia - Spa tourism in Serbia and experiences of other countries", Vrnjačka Banja, 1(2), 153-168.

29. Pantić, N. (2017). Economic effects of tourism development in rural areas of Serbia. The Second International Scientific Conference "Tourism product as a factor of competitiveness of the Serbian economy and experiences of other countries", Vrnjačka Banja, 2(2), 444-459.

30. Pantić, N., Milunović, M., Tankosić, M., Marjanović, N., Krstić, S. (2019). Dependence of Property Incomes and Social Contributions as Indicators of Agro-budgetary Policy Management. Economics of agriculture, Vol. 66, No. 3, 707-720.

31. Sagić, Z., Lakićević, M., Durkalić, D. (2019). Analysis of turnover in a rural tourism destination - Case study of Ivanjica. Economics of Agriculture, Vol. 66, No. 3, 835-850.

32. Slavković, A., Slavković, V. (2019). The importance of training in contemporary organizations. Hotel and Tourism Management, Vol. 7, No. $2,115-125$.

33. Stukalo, V., Krasnikova, N., Krupskyi, P., Redko, V. (2018). Fostering Sustainable Tourism in Global Economy. Revista ESPACIOS, Vol. 39, No. 42, 27-37.

34. Uğur, N. C., Akbiyik, A. (2020). Impacts of COVID-19 on global tourism industry: A cross-regional comparison. Tourism Management Perspectives, Vol. 36, No. 1, 744-756.

35. UNWTO, https://www.unwto.org/international-tourism-and-covid-19, (12 February 2021).

36. WTTC, https://wttc.org/Research/Economic-Impact, (25 February 2021).

37. Zdravković, S., Peković, J. (2020). The analysis of factors influencing tourists' choice of green hotels. Hotel and Tourism Management, Vol. 8, No. 1, 69-78. 